\title{
Supporting Public Health Nurses with Breastfeeding Interventions for Late Preterm Infants
}

\author{
Dosani $A^{* 1,2}$ and Currie $G^{1}$ \\ ${ }^{1}$ School of Nursing and Midwifery, Mount Royal \\ University, Calgary, Alberta, Canada \\ ${ }^{2} \mathrm{O}$ Brien Institute of Public Health, University of Calgary, \\ Calgary, Alberta, Canada \\ *Corresponding author: Dosani A, School of Nursing \\ and Midwifery, Mount Royal University, Calgary, Alberta, \\ Canada
}

Received: May 15, 2017; Accepted: June 19, 2017; Published: J une 26, 2017

\begin{abstract}
Late preterm infants often experience feeding difficulty post discharge from hospital. While breast milk is especially important for late preterm infants, they have lower exclusive breastfeeding rates than full term infants. This is because mothers of late preterm infants often do not receive sufficient amount of breastfeeding support in the postpartum period. Furthermore, in the Canadian context, guidelines do not exist for health care providers to use to assist them in providing breastfeeding support for mother's of late preterm infant in the community setting. We used a modified Delphi approach to begin to fill this gap. We present information relating to physiological development in systems, its significance to feeding, and potential interventions for public health nurses. This information will assist PHNs in their clinical reasoning and decision-making when supporting mothers and their LPIs to exclusively breastfeed in the community.
\end{abstract}

Keywords: Public Health Nurses; Late Preterm Infants; Breastfeeding

\section{Abbreviations}

LPI - Late Preterm Infant; PHN - Public Health Nurses

\section{Introduction}

Late preterm infants (LPIs), born between $340 / 7$ weeks and 36 6/7 weeks gestational age, comprise approximately $75 \%$ of all preterm births [1-3]. While the average rate of preterm birth in Canada is 7.9\%, Alberta (2015-2016) has the highest rate of preterm birth (8.6\%) among the provinces, with Calgary averaging 8.9\% [4]. Historically, various health care providers have managed the care of LPIs similar to that of term infants because of their comparatively large size and seemingly mature appearance $[3,5,6]$. The Canadian Paediatric Society (CPS) supports the early discharge of LPIs if it is safe to do so, as early discharge promotes infant feeding [2]. However, when compared with full term infants, LPIs are at higher risk of experiencing feeding difficulties, which may, in turn, result in excessive weight loss, hypoglycemia, hyperbilirubinemia, and the associated neurologic sequelae [7-13]. Because these medical issues may persist after discharge from hospital, LPIs have a higher rate of emergency room visits and hospital readmission within the first two weeks of life for issues related to feeding, including jaundice and dehydration [14-17].

While LPIs may benefit significantly from breastmilk, they have lower exclusive breastfeeding rates due to mothers receiving inadequate breastfeeding support after birth [18]. Kair and colleagues [19] found that mothers receive inadequate breastfeeding support post discharge. Dosani and colleagues [20] found that not only did mothers have various difficulties with breastfeeding, public health nurses (PHNs) also found it challenging to guide mothers in breastfeeding and provide anticipatory guidance. There are many reasons for this, including limited training received in undergraduate programs [21]. In addition, there are limited guidelines, models of care, and evidence informed standards of community care for LPIs.
PHNs in Alberta therefore must adapt guidelines for term infants to care for LPIs in the community setting, where follow up of the mother infant dyad is provided upon discharge from acute care [22]. As a result, PHNs in Alberta often rely on their empirical knowledge, and perhaps prior experience of caring for term and extremely preterm infants when considering care practices for LPIs [19]. This result in significant variability in the care offered to LPIs in the community setting [23]. Therefore, PHNs require support in caring for LPIs in the community setting in the form of best practice guidelines. We begin to fill this gap by presenting a systems-based breastfeeding framework for LPIs. The information presented in this article will assist PHNs in their clinical reasoning and decision-making when supporting mothers and their LPIs to exclusively breastfeed in the community setting.

\section{Methods}

We conducted a literature search to gather information about medical issues of LPIs and related implications on growth and development and feeding. GC and a research assistant gathered and collated information available in the literature. We used a modified Delphi approach to define the issues and important concepts related to LPIs and feeding, order issues by importance, determine priorities, and identify best practices [24]. This method is commonly used to "obtain the most reliable consensus of opinion of a group of experts" [25]. Ethical approval was received from Mount Royal University Health Research Ethics Board on March 16, 2016. Data were collected between April 2016 - March 2017. Managers of the postpartum community sites sent out an e-mail script inviting the eligible PHNs to participate in the study on behalf of the AD and GC with a date of the first Delphi meeting. GC and a research assistant, aided in the recruitment of eligible PHNs by using the snowball technique. The snowball technique is used to identify interest from people who know people who know participants who are informationrich [26]. Fourteen PHNs with 15-35 years of experience working 
Table 1: Physical Development and Feeding.

\begin{tabular}{|c|c|c|}
\hline What is Happening & Significance to Feeding & How PHNs can Respond \\
\hline $\begin{array}{l}\text { LPIs often look like term infants due to their } \\
\text { respective size (they often weigh between } 4.5 \\
\text { and } 7 \text { pounds) but they are physiologically and } \\
\text { metabolically immature. }[3,5,6]\end{array}$ & $\begin{array}{l}\text { Because of their immaturity, LPIs are } \\
\text { often sleepier, have less stamina, and } \\
\text { have more difficulty with latch, suck, } \\
\text { and swallow than a full-term infant } \\
\qquad[35,36] \\
\text { Infants' physiologic stability alters the } \\
\text { drive to suck and remain alert [37] }\end{array}$ & $\begin{array}{c}\text { Teach parents and caregivers that skin-to-skin contact promotes } \\
\text { physiologic stability [38] }\end{array}$ \\
\hline $\begin{array}{l}\text { LPIs have limited physiological reserves to } \\
\text { respond to stress [39]. }\end{array}$ & $\begin{array}{l}\text { Because of physiologic instability, } \\
\text { LPIs have more difficulty maintaining } \\
\text { temperature, have greater delays } \\
\text { in bilirubin excretion, increased } \\
\text { vulnerability to infection, and more } \\
\text { respiratory instability than the term } \\
\text { infant }[35,36]\end{array}$ & $\begin{array}{l}\text { Physiologic instability may impact the outcome of each feeding. Teach } \\
\text { parents and caregivers to recognize the signs of physiologic instability } \\
\text { and stress that include: change in state of alertness; change in postural } \\
\text { control or tone and movement patterns; change in cardiorespiratory } \\
\text { behavior (change in baseline color to pallor or cyanosis, respiratory } \\
\text { fatigue, tachypnea - greater than } 60 \text { breaths per minute, nasal flaring } \\
\text { and or blanching, chin tugging - a movement in which the infant } \\
\text { extends his/her neck and pulls the chin up in an attempt to open the } \\
\text { airway for breathing, shallow short breaths instead of a series of deep } \\
\text { breaths, bradycardia, apnea); uncoupling of swallowing and breathing } \\
\text { (loss of bolus control orally or drooling; gulping, gurgling sounds in the } \\
\text { pharynx, multiple swallows to clear bolus, coughing and/or choking) } \\
\text { [36,37,40,41,42] } \\
\text { Teach parents and caregivers how to recognize the early signs of stress } \\
\text { and promote conservation of energy. This may set parents and LPIs up } \\
\text { for successful feeding experiences [39] } \\
\text { Assist parents and caregivers to think critically about what they are } \\
\text { observing and respond accordingly. For example, if they are observing } \\
\text { a color change that may be related to shallow breathing, the parent may } \\
\text { provide a break during the feed to provide time and space for the LPI to } \\
\text { breathe deeply. If the color change is related to poor milk control, then } \\
\text { the parent may think about whether the flow rate of milk is appropriate } \\
\text { and potentially investigate swallowing problems [41] }\end{array}$ \\
\hline $\begin{array}{l}\text { During the last } 6 \text { weeks of gestation, fetal muscle } \\
\text { tone increases }[5,40]\end{array}$ & $\begin{array}{c}\text { LPIs ability to feed in terms of } \\
\text { maintain oral motor control is } \\
\text { dependent on their ability to maintain } \\
\text { muscle tone and control throughout } \\
\text { their bodies [6] }\end{array}$ & $\begin{array}{l}\text { Teach parents and caregivers that very subtle changes in } \\
\text { oropharyngeal movements may be the first sign that the infant is losing } \\
\text { control [41] }\end{array}$ \\
\hline $\begin{array}{c}\text { LPIs are at risk for general low muscle tone, } \\
\text { weak muscle tone around the mouth, decreased } \\
\text { tongue strength, and inability to generate a strong } \\
\text { suck and maintain strong vacuum pressure at } \\
\text { the breast. LPIs muscle tone may be adequate at } \\
\text { the start of a feeding but they cannot sustain the } \\
\text { necessary tone to feed as required } \\
{[5,6,40,43]}\end{array}$ & $\begin{array}{l}\text { Decreased muscle strength including } \\
\text { poor oral motor tone of LPIs may lead } \\
\text { to difficulties in latching, sucking, and } \\
\text { swallowing [44] } \\
\text { LPIs appear to go through the motions } \\
\text { of feeding, moving their jaw up and } \\
\text { down but the poor vacuum results } \\
\text { in minimal milk transfer, due to } \\
\text { decreased suckling strength }[5,6]\end{array}$ & $\begin{array}{l}\text { Teach parents and caregivers that LPIs interest in feeding, the length } \\
\text { of time they are able to maintain muscle control and sucking and } \\
\text { swallowing skills may vary from feed to feed [6] } \\
\text { Explain to parents and caregivers that LPIs may require multiple feeding } \\
\text { methods on their journey to exclusive breastfeeding } \\
\qquad[1,35,45]\end{array}$ \\
\hline $\begin{array}{l}\text { LPIs may have difficulties feeding since } \\
\text { the muscles that are implicated in sucking, } \\
\text { swallowing, and breathing develop at different } \\
\text { points in time [46] }\end{array}$ & $\begin{array}{l}\text { The inability to maintain suction } \\
\text { pressure could lead to ineffective } \\
\text { feeding, poor growth, dehydration, } \\
\text { and jaundice } \\
{[22,44,47]}\end{array}$ & $\begin{array}{l}\text { Teach parents and caregivers that when an infant is feeding well, } \\
\text { the following is typically observed: smooth, regular respirations (or } \\
\text { significant increase in respiratory effort than what was observed } \\
\text { before the feeding); infant's hands are actively near the face, strong } \\
\text { and consistent postural control throughout body; the infant's color has } \\
\text { not changed significantly from what was observed before the feeding; } \\
\text { the infant is organized and calm with good coordination of sucking, } \\
\text { swallowing, and breathing; the infant is focused and alert [41] }\end{array}$ \\
\hline $\begin{array}{l}\text { Infants are not able to organize the management } \\
\text { of arousal which is not well established until the } \\
\text { infant reaches } 37 \text { weeks gestation [48] }\end{array}$ & $\begin{array}{c}\text { LPIs tire easily, sleep more frequently, } \\
\text { and have shorter periods of time when } \\
\text { they are awake }[5,6]\end{array}$ & $\begin{array}{l}\text { Teach parents and caregivers that they need to wake their LPI for } \\
\text { feedings [6] }\end{array}$ \\
\hline
\end{tabular}

Table 2: Neurological Development and Feeding.

\begin{tabular}{|c|c|c|}
\hline What is Happening & Significance to Feeding & How PHNs can Respond \\
\hline $\begin{array}{c}\text { The brain and the respiratory system are } \\
\text { the last systems to mature [5] }\end{array}$ & $\begin{array}{c}\text { Implement simple teaching approaches to educate } \\
\text { parents and caregivers about brain development that } \\
\text { takes place from } 34 \text { to } 40 \text { weeks gestation: the brain } \\
\text { of an LPI at } 34 \text { weeks only weighs } 65 \% \text { of a brain of a } \\
\text { responsible for feeding behaviors. Feeding experience and } \\
\text { learned behaviors may have a lesser role to play [49] }\end{array}$ & $\begin{array}{c}\text { term infant; there is a five-fold increase in white matter } \\
\text { between } 35 \text { and } 41 \text { weeks gestation; from } 34-37 \\
\text { weeks gestation, the brain is undergoing significant } \\
\text { development; during the last } 10 \text { weeks of gestation, the } \\
\text { grey matter increases four - fold [50,51] }\end{array}$ \\
\hline
\end{tabular}


There is a crucial period late in gestation that is essential to the development of various structures and pathways in the brain [3]
Neurons in the brain mature and develop brain stem to advanced cortical cognitive functions that continue to develop after the neonatal period $[53,54]$

During 34 - 36 weeks gestation, the brain tissues develop rapidly and this is the timeframe that peak synaptogenesis occurs in the medulla. The central nervous system also matures between 35 and 38 weeks gestation when the coordination to the functions necessary to nipple feed improve $[46,57]$

Many eating behaviors develop in

a sequence from basic to complex movement patterns and that this progression in neurodevelopment establishes the foundation for postnatal

suckling and swallowing skills [58] In preterm infants, oral-motor skills develop between 30 - 45 weeks gestational age. Effective feeding skills require suction and compression, and the ability to move milk back into the pharyngeal area and into the esophagus for swallowing [48]

LPIs' brains are not mature enough and therefore do not have established mechanisms in place to be able to protect the brain from hypoglycemic injury $[12,60]$

(

The success of the feed may also depend on the feeding environment. Some LPIs may not be able to stay focused and organized in environments that are loud, bright, and busy [6] in a hierarchical method from primitive
LPIs' ability to coordinate eating and breathing reflects the neurological development and maturation of the brain $[3,40,48]$

It is especially important for LPIs to receive breastmilk as it provides a rich source of components that assist in brain growth $[49,55]$

Breast milk contains the appropriate amounts of lactose (galactose + glucose) that ensure ample amounts of galactocerebrosides that are necessary for myelinization of the brain [5]

As LPIs grow and mature, they are better able to manage the flow of milk and demonstrate alternating patterns of sucking and breathing. They may begin by sucking for a burst of 3 to 5 sucks and then take a breath while demonstrating tachypnea. The sucking bursts may be longer and the infant may experience oxygen desaturation. The infant will then recover during tachypneic breathing. The infant will be able to better manage sucking, swallowing, and breathing as the sucking bursts and tachypneic catch-up will be shorter in duration. Eventually, the infant will be able to fully coordinate sucking, swallowing, and breathing, as demonstrated by sucking bursts of 20-30 sucks [48]

Severe hypoglycemia can cause neuronal cell death and can result in adverse neurodevelopment [12,61]

Hypoglycemia in the neonatal period is associated with both grey matter injuries and white matter injuries [12]

If neonatal hypoglycemia causes injury to the occipital region in the brain, infants may be at risk for long-term disability, epilepsy, and visual impairment [12]

Most infants that are born prematurely are not able to simultaneously manage all of the neurodevelopmental sensory inputs in order to achieve effective feeding [48]
Teach parents and caregivers the importance of skinto-skin contact as this accelerates brain development in premature infants [38,52]

If the LPI is swaddled during feeds, teach the parents and caregivers to place infant's hands towards the midline and not down at the sides. This positioning supports neurobehavioral principles and helps the infant to self-quiet and remain alert which supports swallowing actions [6]

Teach parents and caregivers who are bottle feeding with artificial breast milk that LPIs may require the artificial breast milk to be fortified with docosahexaenoic acid (DHA) and arachidonic acid as this improves visual acuity and cognitive development [56]

Teach parents and caregivers that the lactose present in breast milk supplies the infant with glactocerebrosides that are required for myelinization of the brain. Infants that are fed soy-based formulas or lactose free cow's milk formulas lack the nutrients needed for brain growth $[5,6]$

Because infants need to coordinate sucking, swallowing and breathing, teach the parents and caregivers not to move the artificial nipple (if bottlefeeding) in the mouth as a way to remind the infant to suck. Teach parents and caregivers that when infants pause, they require this break and the artificial nipple should be allowed to rest in the infant's mouth until he/she is ready to suck again [43]

When breastfeeding, teach mothers to minimize the initial milk flow by expressing some breastmilk just before the feeding. This will help the infant establish suck-swallow-breath coordination [59]

Teach parents and caregivers the significance of establishing regular feeding early on to prevent neurological injury $[12,13]$

Teach parents and caregivers that in order for LPIs' neurological system development, they need to experience touch, massage, gentle rocking, vibration, singing, and they need to hear and see their parents and caregivers. However, they need to be exposed to one activity at a time to prevent sensory overload [52]

Teach parents and caregivers that LPIs are frequently overstimulated and may shut down before consuming amounts of breastmilk that are adequate for growth and development [5]

Encourage parents and caregivers to reduce multiple stimuli during feeding, including distractions from other children, phone conversations, and television [6,52] Teach parents and caregivers that negative feeding experiences may lead to feeding aversions as neurons are being mapped in the brain very quickly $[48,62]$

To eat effectively, infants must be able to sense and react to many inputs comprising tactile, kinesthetic, proprioceptive, olfactory, auditory and visual. In addition to this, infants need to coordinate sucking, swallowing, and breathing all at the same time [48]
LPIs need remain alert in addition to managing the amount, them during any given feeding [48] duration, and timing of sensory input that is demanded of
Teach parents and caregivers to watch for the infant's readiness to feed in terms of attaining and maintaining a quiet state of arousal, a flexed body posture with sufficient muscle tone, the ability to search for the nipple when it is presented, and organize body posture to midline with arms coming forward to assist [43] 
Table 3: Gastrointestinal System and Feeding.

\begin{tabular}{|c|c|c|}
\hline What is Happening & Significance to Feeding & How PHNs can Respond \\
\hline $\begin{array}{l}\text { The nutritive sucking pathway comprises } \\
\text { two connected mechanisms: suck/ } \\
\text { pharyngeal swallow/respiration that is } \\
\text { related to safety and suck/pharyngeal } \\
\text { swallow/esophageal activity } \\
\text { that is about efficiency [46] }\end{array}$ & $\begin{array}{l}\text { LPIs thrive with short frequent feeds at the breast or } \\
\text { bottle of combined feeds of around } 30 \text { minutes total } \\
\text { feeding time [36] }\end{array}$ & $\begin{array}{l}\text { Help parents and caregivers recognize and interpret infant } \\
\text { feeding behavior and develop competence and confidence in } \\
\text { reading their infants cues }[41,48,62] \\
\text { Teach parents and caregivers to differentiate between nutritive } \\
\text { and non-nutritive sucking. Non-nutritive sucking is usually } 2 \\
\text { sucks per second whereas nutritive sucking (and coordination } \\
\text { of swallowing and breathing) is one suck per second [48] } \\
\text { Help parents and caregivers to nurture the feeding relationship } \\
\text { by responding to the LPls communication about the feeding } \\
\text { experience }[41,42]\end{array}$ \\
\hline $\begin{array}{l}\text { LPIs swallowing functions, peristaltic } \\
\text { functions, and sphincter control in the } \\
\text { esophagus, stomach, and intestines are } \\
\text { likely to be less mature [3] }\end{array}$ & $\begin{array}{l}\text { LPIs take longer to feed than term infants and } \\
\text { this longer time frame may result in difficulties } \\
\text { coordinating sucking and swallowing }[3,63]\end{array}$ & $\begin{array}{c}\text { Teach parents and caregivers that the goal of each feeding } \\
\text { session should be an alert infant who allows for adequate } \\
\text { intake without disorganized behaviours such as loss of milk } \\
\text { from the sides of the mouth and pooling of milk in the mouth. } \\
\text { Teach parents and caregivers to be able to identify signals of } \\
\text { stress including, skin pallor, arching, limb extension or turning } \\
\text { away from the breast or bottle [6] }\end{array}$ \\
\hline $\begin{array}{c}\text { LPIs experience transient relaxation of the } \\
\text { lower esophageal sphincter [64] } \\
\text { Motility and gastric emptying is often } \\
\text { delayed in LPIs [3] }\end{array}$ & $\begin{array}{l}\text { Late preterm infants may experience } \\
\text { gastroesophageal } \\
\text { reflux[63]. Severe gastroesophageal reflux may lead } \\
\text { to prolonged apnea and bradycardia [54] } \\
\text { The symptoms of reflux, including frequent spitting } \\
\text { up, vomiting, and apnea may compromise feeding } \\
\text { interactions and feeding outcomes [22] }\end{array}$ & $\begin{array}{c}\text { Teach parents and caregivers to decrease flow of milk by } \\
\text { adjusting the sucking burst length and respond to milk spilling } \\
\text { out of lips with a period of rest. This will allow for the infant to } \\
\text { reorganize swallowing function }[41,62]\end{array}$ \\
\hline $\begin{array}{l}\text { LPIs' anatomy of oral and pharyngeal } \\
\text { structures are not developed well-enough } \\
\text { to facilitate successful breastfeeding. LPIs' } \\
\text { mandible is disproportionately small when } \\
\text { compared to the skull [57] }\end{array}$ & $\begin{array}{l}\text { The tongue of the LPI fills the oral cavity and is in } \\
\text { contact with all areas of the mouth that leaves very } \\
\text { little space for variation in tongue movements [57] }\end{array}$ & $\begin{array}{l}\text { Teach parents and caregivers that if the infant does not open } \\
\text { his or her mouth spontaneously or the mouth does not open } \\
\text { wide enough, they may exert gentle downward pressure on the } \\
\text { infant's chin with their index finger as the infant approaches the } \\
\text { breast [5] } \\
\text { Teach parents and caregivers to be aware of smacking sounds } \\
\text { at the breast as this signals loss of contact between the infant's } \\
\text { tongue and the breast. Instruct the mother that she may apply } \\
\text { sublingual pressure and place her index finger directly behind } \\
\text { and under the tip of the infant's chin where the tongue attaches } \\
\text { to limit the extent of the downward movement of the infant's } \\
\text { jaw [5] }\end{array}$ \\
\hline $\begin{array}{l}\text { LPIs are at increased risk for experiencing } \\
\text { oxidative stress. Necrotizing enterocolitis } \\
\text { is associated with oxidative stress if } \\
\text { the damage that has occurred is in the } \\
\text { digestive tract }[5,65]\end{array}$ & $\begin{array}{c}\text { Breastmilk has been shown to have a higher } \\
\text { antioxidative capacity than infant formula and helps } \\
\text { neutralize oxidative stress [65] }\end{array}$ & $\begin{array}{l}\text { Encourage parents and support them to achieve breastfeeding } \\
\text { success [35] }\end{array}$ \\
\hline $\begin{array}{l}\text { LPIs have immature mucosal immune } \\
\text { systems. They therefore require an external } \\
\text { source of immunosuppression to augment } \\
\text { their developing system and to protect from } \\
\text { harmful pathogens[66] }\end{array}$ & $\begin{array}{l}\text { Infants who are fed human milk have a lower risk of } \\
\text { necrotizing enterocolitis because human milk has } \\
\text { direct immunomodulation effects. Human milk also } \\
\text { has a prebiotic effect of its indigestible complex } \\
\text { carbohydrates (glycans) which has the ability to } \\
\text { inhibit colonization of pathogens }[67,68] \\
\text { Human milk has protective and immunomodulatory } \\
\text { functions that are not present in artificial formulas. } \\
\text { Human milk contains products of the adaptive } \\
\text { immune system of the mother, primarily slgA, and } \\
\text { products of an innate } \\
\text { immune system of human milk }[66,68]\end{array}$ & $\begin{array}{l}\text { Explain to parents and caregivers that the components of } \\
\text { human milk interact with each other and components of the } \\
\text { infant intestinal tract. Explain to parents and caregivers that } \\
\text { some of the components of human milk are only effective at } \\
\text { certain times, locations, and sometimes only in specific types } \\
\text { of individuals. This makes human milk even more powerful in } \\
\text { protecting LPIs against pathogens [66]. }\end{array}$ \\
\hline
\end{tabular}


Infant can only handle small milk volumes initially and this is often inadequate for growth and development [5,6,46,49]
Weight loss of more than $7 \%$ within the first 48 hours puts the LPI at risk for dehydration $[36,49]$

PIs are at an increases risk for excessive weight loss, slow weight gain, failure to thrive, prolonged formula supplementation, exaggerated jaundice, dehydration, breastfeeding failure, and rehospitalization $[16,35,36]$.
Efforts to increase the volume of intake when the LPI is not ready, may result in stressful feeding experiences [37]
The experience of stress during feeding could modify sensory-motor pathways in the brain that result in changes in the infant's ability to feed and alter the infants desire to feed [37]
Coordination of infant suck and swallow is only well established about 34 weeks or later [63]
LPIs take a longer time to achieve normal feeding patterns [3]
Sucking, swallowing, and breathing coordination is not well established until the infant is 37 weeks old $[48,73]$
When oral feeding is initiated early, LPIs have creased opportunities to improve their oral moto skills and gain experience in coordinating sucking, swallowing, and breathing [74]
Teach parents and caregivers how to assess their infant for signs of dehydration: sunken fontanels, dry mucus membranes, and lack of urine output $[40,49]$

Teach parents and caregivers when the LPI experiences excessive weight loss, it may be appropriate to weigh the LPI daily (before and after feeds with an infant weight scale). Weighing should be done when the infant is unclothed and in an environment that is warm enough for the LPI to be unclothed $[49,69]$. Inform parents and caregivers where they may access an infant weight scale in the community.

Teach parents and caregivers that the LPI should be weighed weekly until 40 weeks postconceptual age to ensure that consistent weight gain is evident. Weight gain should average 20 - 30 grams per day [36]

If poor weight gain is identified, the feeding practice and feeding behaviours should be observed every 2-4 days after each adjustment. Interventions should be implemented as appropriate $[6,36,70]$

Explain to parents and caregivers the importance of monitoring voids and stools to determine if feeding intake is adequate: 1 void and $1-2$ stools by day $1 ; 2-3$ voids and at least 1 stool by days 2 and $3 ; 6$ voids and 4 stools by day $4[36,71]$

Teach parents and caregivers that feeding experiences need to be positive and that increases in intake with respect to volume will be the outcome of feeding experiences that are positive $[37,62]$

Teach parents and caregivers that feeding is not only about nutritional intake, but also has social implications in infancy that may last throughout the life span [62]

Teach parents and caregivers to recognize hunger cues and interest in sucking: crying, mouthing, rooting, hands to mouth and sucking movements. Recognizing and responding to subtle cues will increase the oral intake of the infant because less energy is expended trying to alert the parent or caregiver to hunger $[6,72]$

Teach parents and caregivers that an infant who is not ready to feed will not open his or her mouth when the lips are stroked [43]

Teach parents and caregivers to recognize satiation cues: arching of back, pushing away [72]

Teach parents and caregivers to be able to identify signs of feeding disengagement including: coming off breast; pushing the artificial nipple out of mouth, pulling off the nipple, lack of active rooting or sucking, arching the back, inability to remain alert, and using a weak suck to signal the preference to return to non-nutritive sucking $[42,62]$

Teach parents and caregivers that LPIs have weak and subtle feeding cues due to their immaturity. Work with parents and

caregivers to identify the infant's strengths. Use positive reinforcement with parents when they are able to identify their LPI's subtle feeding cues [6]

Teach parents and caregivers that the rhythm and ratio of one suck, one swallow, and one breath does not normally occur until the infant is 37 weeks gestation [73]

Teach parents and caregivers to expect pauses during feeding Infants use these pauses to breath and for coordinating swallowing. Teach parents that infants need to rest just as children pause between bites during a meal [6]

Teach parents and caregivers to learn their infant's communication which will indicate the timing, frequency, and length of the pause required [42]

Teach parents and caregivers to listen for the sound of swallowing in relation to breathing sounds. Swallowing that is quiet and effective will protect the infant from potential choking incidents and allow for breathing in between swallowing efforts to preserve physiologic stability [43]

Teach the parents and caregivers to burp infant half way through feeding

Teach parents and caregivers to observe infant's face while burping in case of cyanosis, or regurgitation 
PIs gastrointestinal tract is not yet colonized with bacteria that convert conjugated bilirubin to urobilinogen [70]
LPIs are at increased risk for developing jaundice $[49,70,75]$
Teach parents and caregivers that LPIs who are breastfed are fed 10-12 times within a 24-hour period. Teach parents and caregivers that LPIs who are bottle fed are fed 8-10 times within a 24-hour period [40]

Table 4: Temperature Regulation and Breastfeeding.

\begin{tabular}{|c|c|c|}
\hline What is Happening & Significance to Feeding & How PHNs can Respond \\
\hline $\begin{array}{c}\text { LPIs have difficulties regulating temperature } \\
\text { because of because of immature epidermal barrier, } \\
\text { high ratio of surface area compared with birth } \\
\text { weight, and the difference between the temperature } \\
\text { of the environment and LPIs' temperature in the first } \\
\text { few days of life [8] }\end{array}$ & $\begin{array}{l}\text { LPIs have reduced glycogen stores, which may } \\
\text { be depleted quickly, and therefore their ability to } \\
\text { produce and conserve heat is limited [76] }\end{array}$ & $\begin{array}{l}\text { Discuss with parents and caregivers the reasons behind } \\
\text { infant's risk for temperature instability. } \\
\text { Review normal temperature range with parents and } \\
\text { caregivers as } 36.5^{\circ} \mathrm{C}-37.4^{\circ} \mathrm{C} \text {. [8] }\end{array}$ \\
\hline $\begin{array}{l}\text { LPIs are at risk for developing cold stress because } \\
\text { they have less subcutaneous fat for insulation, an } \\
\text { immature } \\
\text { epidermis (or thin skin) that serves as a poor barrier } \\
\text { to heat loss. LPIs have a high metabolic rate, but not } \\
\text { enough brown adipose tissue (fat) that is required } \\
\text { to generate heat. They therefore have difficulties } \\
\text { regulating their temperature }[40,52]\end{array}$ & $\begin{array}{c}\text { Cold stress can lead to alterations in glucose } \\
\text { metabolism, decreases in plasma glucose } \\
\text { concentration, respiratory stability, including } \\
\text { pulmonary hypertension, and could potentially lead } \\
\text { to sepsis }[3,8,39,54]\end{array}$ & $\begin{array}{l}\text { Teach parents and caregivers to monitor their LPI's } \\
\text { temperature. Neonatal hypothermia occurs when the } \\
\text { axillary temperature reads below } 36.5^{\circ} \mathrm{C} \text {. [8,77] } \\
\text { Teach parents and caregivers that during the first } \\
\text { few days of life, a normal body temperature }\left(37^{\circ} \mathrm{C}\right) \\
\text { may not be enough to determine whether the thermal } \\
\text { environment is optimal for LPIs. Clinical signs of cold } \\
\text { stress, including peripheral } \\
\text { vasoconstriction may be observed [12] }\end{array}$ \\
\hline $\begin{array}{l}\text { It is during the last } 6 \text { weeks of gestation, } \\
\text { subcutaneous tissue and brown fat are deposited } \\
\text { and glycogen stores increase in the liver [5] }\end{array}$ & $\begin{array}{c}\text { Hypoglycemia may develop secondary to } \\
\text { hypothermia because glucose is used to stimulate } \\
\text { brown fat metabolism }[40,45,76]\end{array}$ & $\begin{array}{c}\text { Explain to parents and caregivers that maintaining } \\
\text { normal temperature helps LPIs to regulate their energy } \\
\text { use and glucose metabolism [52] }\end{array}$ \\
\hline $\begin{array}{c}\text { The term infant produces heat by the oxidative } \\
\text { metabolism of brown fat which results in non- } \\
\text { shivering thermogenesis. LPIs are unable to produce } \\
\text { heat this way because their sympathetic nervous } \\
\text { system is underdeveloped [54] }\end{array}$ & $\begin{array}{c}\text { Hypothermia in LPIs increases the energy } \\
\text { demands required to respond to decreased } \\
\text { temperature. LPIs have limited glycogen stores } \\
\text { which will deplete quickly when the glycogen is } \\
\text { used to help regulate temperature. This will result in } \\
\text { hypoglycemia [40] }\end{array}$ & $\begin{array}{l}\text { Teach parents and caregivers how to appropriately } \\
\text { implement skin-to-skin contact: placing an infant wearing } \\
\text { only a diaper on a parent's or caregiver's bare skin with } \\
\text { an over-covering [52] } \\
\text { Discuss with parents and caregivers what appropriate } \\
\text { room temperature is for LPIs and how to dress the LPI } \\
\text { infant appropriately. Consider exposure to environmental } \\
\text { conditions and dress appropriately in layers; include } \\
\text { socks and head cover when outside } \\
\text { Teach parents and caregivers to anticipate and } \\
\text { recognize the signs and symptoms of hypoglycemia [60] }\end{array}$ \\
\hline $\begin{array}{c}\text { LPIs have less white adipose tissue to insulate } \\
\text { themselves with and they have a limited ability to } \\
\text { produce heat from brown adipose tissue [1] } \\
\text { LPIs are also at risk for losing heat more quickly } \\
\text { because they have a larger surface area to weight } \\
\text { ratio, are smaller in size than term infants and have } \\
\text { a higher body water content than term infants }[1,40]\end{array}$ & $\begin{array}{c}\text { Cold stress causes tachypnea, pallor due to } \\
\text { peripheral vasoconstriction, potential for metabolic } \\
\text { acidosis, and elevated axillary temperatures due to } \\
\text { metabolism of brown fat }[8,39]\end{array}$ & $\begin{array}{l}\text { Discuss with parents and caregivers that skin-to-skin } \\
\text { contact stabilizes their infant's temperature, breathing, } \\
\text { and heart rate. Skin-to- skin contact reduces infant } \\
\text { crying, promotes bonding, and improves breastfeeding } \\
\text { [52] }\end{array}$ \\
\hline
\end{tabular}

Table 5: Cardio respiratory System and Breastfeeding. What is Happening
Significance to Feeding

LPIs can experience stress when feeding. They respond to this stress by indicating their ability to cope with that stress with their heart and respiratory rates, how hard they work to breathe, their oxygen saturations, and their suckswallow-breathe synchrony $[37,42]$
Cardiorespiratory instability can affect control of the larynx, pharynx, and esophagus. It is possible for the infant to experience laryngeal penetration or aspiration, as a result $[37,42]$ When an infant has trouble coordinating swallowing and breathing, he/she may stop sucking even though they are awake and hungry [42]
How PHNs can Respond

Explain to parents and caregivers that feeding is the infant'saerobic exercise and similar to how adults respond to exercise, infants also need to match oxygen requirements to activity. This includes the rate and depth of breathing, any changes in heart rate, any changes that occur in the rate and depth of breathing, and the shape of the airway. It is these changes in respiratory effort that can significantly impact their energy levels and endurance which will lead to lack of coordination of sucking, swallowing, and breathing [41] Instruct parents and caregivers to watch for signs of stress including apnea (a pause in breathing lasting longer than 20 seconds), decreased heart rate (less than 80 beats per minute), rapid breathing, nasal flaring or blanching, chin tugging, eyebrow lifting, shallow short breaths instead of a series of deep breaths, changes in skin color, loss of state arousal, loss of postural control, tone, or movement patterns $[37,43,49]$

Teach parents and caregivers that when infants experience stress, parents will observe a loss of coordination between swallowing and breathing that will present as drooling, gulping, curgling sounds on the pharynx, high pitched crowing sounds, multiple attempts to swallow the milk that is in the infant's mouth, coughing, and choking $[37,41,43]$

Teach parents and caregivers the importance of supporting feeding success by employing the infant's cues to guide their decision-making and actions about how to progress with the feeding. Parents and caregivers can respond to their infant's cues of stress by offering a side-lying position, swaddling their infant in a way that supports and optimizes postural stability, offering pacing during the feeding to ensure that swallowing and breathing is coordinated, and employing gentle techniques to calm the infant or re-arouse the infant [37] Encourage early skin-to-skin contact as this increases cardiorespiratory stability in LPIs [78] 
Brainstem development and neural control of respiration are less developed in LPIs [54]

Late preterm infants have a greater risk for developing respiratory distress. This may be related to transient tachypnea of the newborn, surfactant deficiency, pneumonia, pulmonary hypertension, and experiencing extreme hypoxic events $[10,13,79,80]$

Due to their relatively mature appearance, their birth weight and a misleading clinical picture, the severity of respiratory disease in LPIs is often underestimated [13]

LPIs are at risk for difficulties clearing amniotic fluid from their lungs and producing surfactant, and may have difficulties with expanding alveoli and lung perfusion $[3,13,52]$. Respiratory issues could also result from a deficiency in surfactant [3]

Due to the immature respiratory control centre (maturity of airway and chemical control of breathing) and/or immature respiratory reflexes, LPIs may develop apnea $[40,76]$

LPIs require sufficient oxygenation as this provides the energy for the physiologic work of effective feeding [43]

fants who become drowsy or fall asleep during feeding may be exhibiting respiratory fatigue related to feeding too fast, inadequate oxygenation, or excessive respiratory effort [41]

energy stores, LPIs may fatigue quickly and show signs of falling asleep or shutting down during a feed [52]
The same reflexes that are responsible for clearing oral and nasal secretions, and respiration, need to work together in order for a feeing to be successful [54] and apnea during feeding since the neurological and anatomical structures in the upper airway are common for both respiration and feeding [54]

Discuss with parents and caregivers the importance of monitoring the infant's physical efforts during and immediately following feeding, including burping, such as work of breathing, skin color, and behavio

LPIs are at risk for developing comorbidities including transient tachypnea of the newborn, pulmonary hypertension, and respiratory failure $[3,10]$

The immature respiratory control centre and immature respiratory reflexes lead to uncoordinated suck, swallow, and breathing patterns in LPIs [76]

When LPIs do not receive an adequate level of oxygen in their bodies, this contributes to fatigue that is experienced during feeding. The end result of inadequate oxygenation is shorter feedings, and decreased caloric intake [43]

LPIs look misleadingly exuberant at feeding times but can quickly lose state organization and energy to finish eating $[35,41,48]$

LPIs have higher energy demands and therefore require more rest and short frequent feeds [52]

LPIs have less stamina to latch on to the breast [48]

Infants who do not appear to have sufficient energy to feed are more vulnerable to physiologic stress and are at risk for aspiration because they are less able to cue their caregiver that assistance is required [6]
Teach parents and caregivers to avoid prodding the infant. This includes pulling the artificial nipple in and out, twisting or turning the nipple, jiggling the nipple, rhythmically squeezing the infant's cheeks, or manually moving the infant's jaw up and down as these actions make the coordination of swallowing and breathing more difficult $[37,43]$
Emphasize to parents and caregivers that the feeding experience is a journey; oral-motor skills develop in an organized, observable progression for the healthy preterm infant, but are negatively influenced by medical comorbidities [48]

Teach parents and caregivers that their LPI may be fussy due to inability to protect his/her airway [41]

Teach parents and caregivers to recognize that when an infant is experiencing trouble breathing, sucking patterns may change, jaw and tongue movements may be limited to reduce the amount of milk entering the mouth, the nipple may be pushed out of the mouth and sucking may stop, or, the infant may fall asleep [37]

Teach parents and caregivers the signs of sleepiness/fatigue: not cueing for feeds by 3 hours, not easily awakened, falling asleep before sufficient milk volume has been taken, requiring more frequent breaks [52] Teach parents and caregivers that increasing fussiness displayed by their infant may be a sign of inadequate oxygenation in response to the increased demands of feeding [41]

Teach parents and caregivers that LPIs need to be fed at least every 3 hours. Teach parents and caregivers to wake the infant for feedings if they do not wake themselves [52]

Teach parents and caregivers to identify signs of decreased endurance including decreased arousal, fatigue, and disinterest in feeding, not rooting/ closed lips, poor sucking, turning away from breast, pushing nipple out of mouth, not actively sucking, closing mouth, and sleeping. Teach parents to provide frequent breaks as appropriate $[6,43]$

Teach parents and caregivers that use of a nipple shield may facilitate longer sucking bursts and longer periods of wakefulness [81]

Table 6: Hepatic System and Feeding.

\begin{tabular}{|c|c|c|}
\hline What is Happening & Significance to Feeding & How PHNs can Respond \\
\hline $\begin{array}{l}\text { LPIs have immature hepatic } \\
\text { functions that place them at } \\
\text { increased risk for developing } \\
\text { significantly elevated serum } \\
\text { bilirubin levels }[1,13,16,70,82 \text {, } \\
\text { 83, 84] } \\
\text { LPIs have an increased bilirubin } \\
\text { load on the hepatocyte. This is due } \\
\text { to decreased erythrocyte survival, } \\
\text { increased erythrocyte volume, and } \\
\text { increased enterohepatic } \\
\text { circulation of bilirubin. LPIs also } \\
\text { experience decreased hepatic } \\
\text { uptake of bilirubin from plasma and } \\
\text { have defective bilirubin conjugation } \\
\text { mechanisms [70] }\end{array}$ & $\begin{array}{l}\text { Any visible jaundice within the first } 24 \text { hours of life requires } \\
\text { further investigation because this is an indication of an } \\
\text { underlying pathologic process [85] } \\
\text { Jaundice is the leading cause of rehospitalisation in the late } \\
\text { preterm infant }[70,86]\end{array}$ & $\begin{array}{l}\text { Teach parents and caregivers how to identify hyperbilirubinemia. } \\
\text { Jaundice is usually first noticed in the head, especially the sclera } \\
\text { and mucous membranes, and then progresses to the thorax, } \\
\text { abdomen and then to the extremities [85]; the higher the serum } \\
\text { bilirubin, the greater the surface area of the skin that is yellow } \\
\text { [87]. Every newborn needs to be assessed for jaundice. In order } \\
\text { to identify jaundice, the Registered Nurse applies pressure with } \\
\text { a finger over a bony area (e.g. nose or forehead) for several } \\
\text { seconds to empty all of the capillaries of blood in that area. If } \\
\text { jaundice is present, the blanched area will look yellow, before } \\
\text { the capillaries refill with blood [85]. Use a transcutaneous } \\
\text { monitor to measure bilirubin level if available in your facility since } \\
\text { transcutaneous protocols developed for full term infants are valid } \\
\text { for LPIs in the first } 3 \text { days of life [88]. } \\
\text { Check that a total serum bilirubin has been drawn prior to } \\
\text { discharge. Total serum bilirubin levels are the gold standard for } \\
\text { evaluating hyperbilirubinemia [84,87]. }\end{array}$ \\
\hline
\end{tabular}




\begin{tabular}{|c|c|c|}
\hline $\begin{array}{l}\text { LPIs have decreased serum } \\
\text { bilirubin binding capacity because } \\
\text { they have: lower } \\
\text { serum albumin levels, } \\
\text { enhanced permeability of the } \\
\text { blood- brain barrier to } \\
\text { unconjugated bilirubin influx, and } \\
\text { immaturity of } \\
\text { neuronal protective mechanism } \\
\text { [3,75] } \\
\text { LPIs are at higher risk of developing } \\
\text { kernicterus and its related } \\
\text { neurologic sequalae [13,75,89]. } \\
\text { This is because LPIs demonstrate } \\
\text { signs of bilirubin neurotoxicity at an } \\
\text { earlier postnatal age than infants } \\
\text { who are born at term }[70,75]\end{array}$ & $\begin{array}{l}\text { Severe hyperbilirubinemia is a medical emergency } \\
\text { requiring immediate treatment }[84,90] \text {. Severe jaundice } \\
\text { is accompanied by the following signs and symptoms: } \\
\text { persistent sleeping, difficulty rousing for feedings, a lack } \\
\text { of interest in feedings, decreased muscle tone, a sunken } \\
\text { anterior fontanel (soft spot) indicative of dehydration, and } \\
\text { decreased urine and fecal output [90] }\end{array}$ & $\begin{array}{l}\text { Timely outpatient follow-up for LPIs is essential to prevent severe } \\
\text { jaundice [44] } \\
\text { The ultimate goal of identifying and treating jaundice is the } \\
\text { prevention of kernicterus, defined as permanent brain cell } \\
\text { damage caused by elevated bilirubin levels [11] } \\
\text { Teach parents and caregivers who have LPIs with additional risk } \\
\text { factors (use of instrumentation during delivery, male sex, born to } \\
\text { a mother who was older than } 25 \text { years of age) to be more vigilant } \\
\text { in watching for jaundice [91,92] }\end{array}$ \\
\hline $\begin{array}{l}\text { Significant elevation of serum } \\
\text { bilirubin is caused by an imbalance } \\
\text { between bilirubin production and } \\
\text { bilirubin elimination [84] } \\
\text { Neonates with high bilirubin } \\
\text { production may not develop high } \\
\text { serum levels if fecal excretion is } \\
\text { not impaired; conversely, neonates } \\
\text { with low bilirubin production may } \\
\text { develop high serum levels if fecal } \\
\text { excretion is impaired [84] }\end{array}$ & $\begin{array}{c}\text { Inadequate feeding, and the resulting dehydration, can lead } \\
\text { to increased bilirubin in the blood by increasing bilirubin } \\
\text { reabsorption in the intestines } \\
\qquad[3,40,70,75]\end{array}$ & $\begin{array}{l}\text { Typically, hyperbilirubinemia is treated by correcting the } \\
\text { dehydration, encouraging increased frequency of feedings to } \\
\text { promote fecal excretion of bilirubin, phototherapy, and rarely, } \\
\text { exchange transfusion [70,87,90]. } \\
\text { Instruct parents and caregivers to feed up to } 12 \text { times per } 24 \\
\text { hours in their first few days of life in order to prevent jaundice [93] }\end{array}$ \\
\hline $\begin{array}{l}\text { LPIs present with greater severity } \\
\text { of jaundice and more protracted } \\
\text { jaundice than term infants }[10,70]\end{array}$ & $\begin{array}{l}\text { LPIs who are fed breast milk, either through breastfeeding } \\
\text { or expressed breast milk, are at increased risk for severe } \\
\text { hyperbilirubinemia [70] } \\
\text { Breast milk-induced jaundice occurs in infants who consume } \\
\text { sufficient amounts of breast milk but it is unclear how the } \\
\text { components of breastmilk contribute to hyperbilirubinemia } \\
{[94]}\end{array}$ & $\begin{array}{c}\text { Explain to parents and caregivers that the benefits of breast } \\
\text { milk feeding (versus formula feeding) outweigh the risks of } \\
\text { hyperbilirubinemia [70] } \\
\text { Provide close follow-up and lactation support within the first } 48 \\
\text { hours of discharge }[49,70]\end{array}$ \\
\hline $\begin{array}{l}\text { Due to hepatic immaturity, LPIs } \\
\text { may have a delay in hepatic } \\
\text { glucose-6-phosphatase activity [3] } \\
\text { LPIs have lower accumulation of } \\
\text { glycogen reserves in the hepatic } \\
\text { system which are depleted very } \\
\quad \text { quickly after birth [12] }\end{array}$ & $\begin{array}{l}\text { Glucose-6-phosphatase is an enzyme that hydrolyzes } \\
\text { glucose-6-phosphate into phosphate and glucose and } \\
\text { therefore plays a key role in the homeostatic regulation } \\
\text { of blood glucose level as this is the primary biochemical } \\
\text { response to hypoglycemia [3] } \\
\text { The LPI is at risk for developing hypoglycemia [35] } \\
\text { LPIs experience a greater decrease in postnatal plasma } \\
\text { glucose concentrations than term infants [12] }\end{array}$ & $\begin{array}{c}\text { Teach parents and caregivers to recognize the signs and } \\
\text { symptoms of hypoglycemia which include changes in level of } \\
\text { consciousness (irritability, excessive crying, lethargy or stupor); } \\
\text { apnea and cyanosis; poor feeding; tachypnea, tachycardia, } \\
\text { grunting; hypothermia; hypotonia - limpness; tremor-seizures, } \\
\text { and jitteriness [12] }\end{array}$ \\
\hline
\end{tabular}

with breastfeeding mothers were recruited from three postpartum community sites (North, South, and East) in Calgary, Alberta, Canada. Ten of the 14 PHNs were certified lactation consultants.

Informed consent was verbally discussed with potential participants on the day of the Delphi meetings. Written consent was obtained. Participants were informed that they may withdraw from the study at any time. Due to the nature of the Delphi technique, that comments are used to build consensus, study participants were informed that if they chose to withdraw from the study, data cannot be removed. We employed a "real-time" Delphi, in which multiple rounds were compressed to occur over several meetings [24]. We used three rounds of questioning. In the first round, called the exploration phase [27], PHNs explored the challenges they experienced when working with breastfeeding LPIs using broad open-ended questions. Each subsequent round then became part of an "evaluation phase" [27], where the results of the previous round were used to frame another set of questions. Each round provided an opportunity for the experts to respond to and revise their answer in light of other group members' previous responses. Over multiple rounds, the process gradually led to consensus or near-consensus [24]. After the Delphi rounds AD ensured all current literature was included until saturation was reached and critically synthesized the information according to systems and important concepts.

\section{Results and Discussion}

Pertinent information relating to growth and development connected to various systems and other factors, why this is relevant to feeding, and how the PHN can respond in practice to promote breastfeeding success, are presented in Tables 1 - 9 .

As demonstrated in Tables 1 - 9, LPIs experience significant feeding challenges that are related to systems development and other factors including positioning and maternal physiology. It is imperative that all health care providers who work with LPIs and their families understand the significant feeding challenges experienced by LPIs and how this relates back to physiological systems maturation. It is especially important for PHNs to be aware of the myriad of factors that could potentially contribute to feeding difficulties in the LPI population, given the continuing trend of early discharge of neonates after birth, including LPIs [2]. Parental anxiety and feeling overwhelmed, fatigued, and stressed are very common with parents caring for LPIs and, as a result, parents require adequate community health care supports at home, particularly with regards to feeding challenges [28]. PHNs are well-positioned to provide information and education, support, and anticipatory guidance, and this has the potential to have a lasting impact on parents and newborns [29]. 
Table 7: Transition to Exclusive Breastfeeding.

\begin{tabular}{|c|c|}
\hline What is Happening & Significance to Feeding \\
\hline $\begin{array}{l}\text { LPIs have immature and inconsistent } \\
\text { feeding behaviours (e.g. feeding cues, } \\
\text { number of sucks, duration of sucking bursts, } \\
\text { and sucking pressure) which may make } \\
\text { it challenging for mothers to breastfeed } \\
\text { effectively and establish and sustain an } \\
\text { adequate milk supply }[31,45]\end{array}$ & $\begin{array}{l}\text { LPIs are at an increased risk for experiencing } \\
\text { breastfeeding difficulties and often require } \\
\text { breastfeeding assistance after discharge from } \\
\text { hospital [9] }\end{array}$ \\
\hline $\begin{array}{l}\text { LPIs may be discharged home after } \\
\text { successful transfer to the extrauterine } \\
\text { environment, but before lactogenesis II is } \\
\text { completely developed, before problems with } \\
\text { latch and milk transfer are identified, and } \\
\text { adequately addressed [36] }\end{array}$ & $\begin{array}{l}\text { LPIs who are discharged within } 48 \text { hours of birth are } \\
\text { at increased risk of breastfeeding difficulties [49] } \\
\text { Supplementation may be required if the infant } \\
\text { cannot obtain an adequate amount of colostrums/ } \\
\text { milk directly from the breast, with the use of frequent } \\
\text { cue - based feeds. This includes circumstances in } \\
\text { which the mother has tried breast massage and } \\
\text { compression, use of a nipple shield, and use of } \\
\text { incentives at the breast [5] }\end{array}$ \\
\hline & \\
\hline
\end{tabular}

Discuss feeding goals with mother [36,69]. Teach parents and caregivers that skin-to-skin contact is associated with an earlier establishment of exclusive breastfeeding [38]. Review feeding plan with parents and caregivers including specifics regarding frequency, approximate duration of feedings, and how baby is being fed (e.g., at the breast, use of a nipple shield, expressed breast milk with supplemental device such as supplemental nursing system, finger feeds, cup or bottle [36]. Some LPIs may require increased caloric intake for a period of time under the guidance of a registered dietitian. It may be necessary to implement individualized feeding plans that are based on the LPIs growth, quality of growth, and the potential for nutrient deficiencies [44]. Discuss with parents and caregivers the type of nipple and flow rate to purchase. Artificial nipples with too high a flow-rate increase the likelihood that infant will lose control of the bolus of liquid in his mouth [41]. Slower flow rates, gives infants time to organize suck, swallow, and breathe [47]. Explain to parents and caregivers to treat the bottle like the breast: improved physiological stability (measured in heart rate and oxygen saturation) may be promoted in LPIs using elevated side lying position to feed [95]. Teach parents and caregivers to offer and wait for infant to invite nipple into their mouth [6]. Teach parents and caregivers to wait for the wide gape before putting artificial nipple in to infant mouth. Teach parents and caregivers to minimize pacifier use for earlier establishment of exclusive breastfeeding [96]

Teach parents and caregivers that the appropriate amount of colostrum to be offered to the infant every $2-3$ hours within the first few days of life generally are: $5-10 \mathrm{ml}$ on day one, $10-20 \mathrm{ml}$ on day 2 , and $20-30 \mathrm{ml}$ on day 3 [52]. Teach the mother that she may massage her breast and compress her breast when the infant is pausing between sucking bursts. This will compensate for a weak vacuum and will increase milk transfer to the infant. This technique will also improve the pressure gradient between the breast and the infant's mouth [5]. Teach parents and caregivers that the benefit of using cup feeding during supplementation is that it allows the infant to use the masseter and temporalis muscles which is similar to their muscle functioning while breastfeeding [99]. Teach parents and caregivers that finger feeding with a tube device necessitates the infant to generate and sustain a vacuum to remove the milk [5]. Explain to parents and caregivers that bottle feeding is different from, and not necessarily easie than, breastfeeding. During breastfeeding, it is the infant that paces the feeding and is an active participant [59]

Provide lactation support when required [3]. A referral to a lactation consultant should be viewed with the same medical urgency as any othe acute medical urgency $[35,36]$. Teach parents and caregivers that cup feeding (versus bottle feeding) significantly increased the likelihood that LPIs will be exclusively breastfed at 3 months and 6 months [100]. If the LP is unable to cup feed, teach parents and caregivers how to assist the infant to latch with a milk-filled dropper or a syringe or tube feeding device. These

Some infants may engage in rapid side-toside head movements that make latching difficult and/or painful [5]
Preterm infants have significantly lowe suction pressures than term infants $[59,81,101]$
LPIs may require multiple sessions with lactation consultants or experienced PHNs before they are able to establish nutritive breastfeeding. They will often require supplementation with expressed established [35] breast milk or formula until nutritive breastfeeding is devices may be filled with colostrums or breast milk and placed at the side of the infant's mouth as they latch on. As the infant is about to latch, a few drops of colostrums or milk is delivered from the dropper/syringe/tube that instigates a swallow. When the infant's mouth comes into contact with the device, it eliminates the side-to-side head movements and orients the infant to the breast. The initial drops of colostrum or milk encourages the infant to swallow, followed by a nutritive suck [5]. If the above latching techniques are unsuccessful, teach the mother how to use a nipple shield. Teach mothers that they may hand express (or use a syringe to pre-fill) colostrum/ milk into the nipple shield tunnel to give the infant an immediate sucking reward [5]. Provide regular follow-up, and access to lactation support when required, to ensure that successful exclusive breastfeeding can be accomplished $[3,35,70]$

Teach mothers how to use a nipple shield because the use of nipple shields will help the infant maintain suction pressures necessary to remove milk from the breast and increase breast milk transfer $[59,81]$

LPIs may have difficulty maintaining a sustained latch to the maternal breast [59]
Teach parents and caregivers that the use of a nipple shield will ensure the infant does not slip off the breast during pauses of sucking bursts $[46,81]$ 
Table 8: Physical Positioning and Feeding.

\begin{tabular}{|c|c|c|}
\hline What is Happening & Significance to Feeding & How PHNs can Respond \\
\hline $\begin{array}{c}\text { LPIs are at risk for experiencing } \\
\text { positional apnea caused by airway } \\
\text { obstruction, bradycardia, and oxygen } \\
\text { desaturation when they are placed in } \\
\text { positions that create excessive flexion on } \\
\text { the neck and trunk [5] }\end{array}$ & $\begin{array}{c}\text { When the mother is semi-reclined during breastfeeding with the infant } \\
\text { paced prone, this positioning stimulates feeding reflexes, improves } \\
\text { ventilation, and increases skin-to-skin contact [102] }\end{array}$ & $\begin{array}{c}\text { Teach parents and caregivers the importance of } \\
\text { promoting a feeding position that is supportive } \\
\text { and developmentally focused. This means that } \\
\text { the infant's head and neck should be in a neutral } \\
\text { position and should align to his or her trunk [6] } \\
\text { Instruct mothers to position infants in a cross } \\
\text { cradle, clutch or ventral (prone) position during } \\
\text { breastfeeding. Teach parents to avoid the cradle } \\
\text { hold [5] }\end{array}$ \\
$\begin{array}{c}\text { LPIs may not have the neurological } \\
\text { maturity to maintain their airway while } \\
\text { positioned in a properly installed car seat } \\
\text { or other devices that are designed to } \\
\text { support the infant in an upright position } \\
\text { [52] }\end{array}$ & $\begin{array}{c}\text { Positioning in a car seat or other devices that are designed to support } \\
\text { the infant in an upright position may result in apnea, bradycardia, } \\
\text { or oxygen desaturation [52]. LPIs have are not able to ventilate } \\
\text { themselves appropriately in response to hypoxia [54]. Therefore, if } \\
\text { feeding if an infant is in a car seat or other devices, or immediately } \\
\text { after removing the LPI from the car seat or other device, they may not } \\
\text { be ready to feed. }\end{array}$ & $\begin{array}{c}\text { Teach parents and caregivers never to feed an } \\
\text { LPI while in a car seat. Instruct parents to never } \\
\text { leave an LPI unattended in a car seat and should } \\
\text { spend limited time in devices that are meant to } \\
\text { support infants in an upright position [52] }\end{array}$ \\
\hline
\end{tabular}

Table 9: Maternal Physiology and Feeding.

\begin{tabular}{|c|c|c|}
\hline What is Happening & Significance to Feeding & How PHNs can Respond \\
\hline $\begin{array}{l}\text { If the maternal nipple is too large or flat, the } \\
\text { LPI will slip off of the breast completely as the } \\
\text { mandible closes [81] }\end{array}$ & $\begin{array}{l}\text { The LPI's inability to remove milk from } \\
\text { the mother's breast effectively results } \\
\text { in delayed lactogenesis II and this } \\
\text { may decrease milk volume within the } \\
\text { first few days after birth [47] }\end{array}$ & $\begin{array}{l}\text { Teach mothers that the use of a nipple shield will correct flat and/or large } \\
\text { nipples which will make it easier for the LPI to maintain a latch and extract } \\
\text { milk and will also increase breast stimulation which, in turn, may contribute } \\
\text { to milk production [81] } \\
\text { Teach mothers how to massage their breasts to express colostrum (more } \\
\text { than } 5 \text { times per day in the first } 3 \text { days) and how to use hands on pumping to } \\
\text { express mature milk [103] } \\
\text { Teach mother to increase milk yield by combining manual expression, breast } \\
\text { compression, and use of an electric breast pump [103] } \\
\text { Teach parents that because of the unique qualities of LPIs, } \\
\text { immediate and frequent } \\
\text { pumping is the primary driver of milk supply, not the LPIs suckling at the } \\
\text { breast [49] }\end{array}$ \\
\hline $\begin{array}{l}\text { Women with the following conditions may be } \\
\text { at risk for delivering a LPI: multiple pregnancy, } \\
\text { diabetes, pregnancy induced hypertension, } \\
\text { prolonged rupture of membranes, } \\
\text { chorioamnionitis, oxytocin induction, or a } \\
\text { cesarean section delivery [35] }\end{array}$ & $\begin{array}{c}\text { Any one, or a combination, of } \\
\text { these conditions places the infant } \\
\text { at increased risk for breastfeeding } \\
\text { difficulty [35] }\end{array}$ & $\begin{array}{l}\text { Timely evaluation of the LPI after discharge is critical to promote the health } \\
\text { of both mother and infant [35] }\end{array}$ \\
\hline $\begin{array}{l}\text { LPIs may be discharged before effective } \\
\text { lactation is established [44] }\end{array}$ & $\begin{array}{l}\text { Mother's milk supply may not meet } \\
\text { infant's required volumes for age. } \\
\text { Infant may require supplementation }\end{array}$ & $\begin{array}{l}\text { Encourage mothers to use an electric double pump to pump their breasts } \\
\text { every two to three hours if: they are experiencing a delay in their milk supply, } \\
\text { they notice that their infants have a weak suck, their infant is receiving } \\
\text { supplementation, or are unable to feed due to illness [52] } \\
\text { Teach mothers that early pumping and establishment of maternal milk } \\
\text { supply within the first week will lead to longer breastfeeding duration [49] } \\
\text { Teach mothers that they may express more colostrum manually (hand } \\
\text { expression) during the first } 48 \text { hours post birth than with the use of an } \\
\text { electric pump [103,101] } \\
\text { Encourage parents and caregivers to use expressed breast milk (EBM) } \\
\text { when possible } \\
\text { Teach parents and caregivers about the special handling of expressed } \\
\text { breast milk or formula } \\
\text { Observe interactions between LPI and mother especially if there has been a } \\
\text { separation in hospital } \\
\text { Provide supports for Postpartum Depression as needed }\end{array}$ \\
\hline $\begin{array}{l}\text { Mothers may experience areolar edema [5] } \\
\text { If the mother is experiencing engorgement, } \\
\text { expanded circulation and excess of interstitial } \\
\text { fluid compete for space as milk volumes } \\
\text { increase [105] }\end{array}$ & $\begin{array}{l}\text { Areolar edema and engorgement may } \\
\text { result in difficulty latching, delayed } \\
\text { milk ejection, poor milk transfer to } \\
\text { infant, pain, and nipple damage [105] }\end{array}$ & $\begin{array}{l}\text { Teach mothers the technique of reverse pressure softening: before each } \\
\text { attempt to latch, hand express, or pump, apply gentle, but firm pressure on } \\
\text { a } 1-2 \mathrm{~cm} \text { radius of the center of the areola, in the place where it connects } \\
\text { with the base of the nipple. Apply the pressure in an inward direction that } \\
\text { is perpendicular to the mother's chest wall. The act of reverse pressure } \\
\text { softening should last between 1-3 minutes. This intervention may be } \\
\text { implemented once or more, depending on how severe the edema is. } \\
\text { Mothers may implement this reverse positive pressure until engorgement } \\
\text { resolves and latching becomes easier [105] } \\
\text { Teach mothers that reverse pressure softening reduces the resistance of the } \\
\text { subareolar tissue while freeing it temporarily to interact more efficiently with } \\
\text { the infant's mouth. The reverse pressure softening technique also triggers } \\
\text { the milk ejection reflex [106] }\end{array}$ \\
\hline
\end{tabular}


Mothers are responsive to interventions regarding their breastfeeding practices delivered in the community setting [30]. We, therefore, offer that the education, support, and anticipatory guidance that $\mathrm{PHNs}$ can provide in the immediate postpartum period may increase the competence and confidence of mothers, families, and other caregivers to provide the type of care that is specific to the LPI population. Mothers' confidence in caring for LPIs depends on their ability to understand what is happening in terms of physiologic and neurologic development and to recognize related infant cues and appropriately respond to them [31]. Likewise, maternal confidence is also impacted by infants' positive responses to the type of care offered [32]. Maternal confidence is significant because it impacts breastfeeding duration [33]. Furthermore, breastfeeding the LPI is a complex and tenuous process that is influenced by many factors which ultimately determines whether, or not, breastfeeding is continued [34]. Therefore, appropriate and timely support in the postnatal period by public health nurses is critical to the health and wellbeing of LPIs, mothers, and families.

\section{Conclusion}

Based on a review of the literature and our previous research experience [20,23], mothers and families of LPIs require an additional level of care in terms of information and education, support, and anticipatory guidance from $\mathrm{PHNs}$ with respect to breastfeeding. We offer a systems-based approach to bridge the information from the literature and input from PHN stakeholders, using a modified Delphi approach. This information will help guide PHNs and other health care professionals, who care for the vulnerable LPI population in the community setting, with clinical reasoning and decision-making with respect to breastfeeding.

\section{References}

1. Engle WA, Tomashek KM, Wallman C. "Late-preterm" infants: a population at risk. Pediatr. 2007; 120: 1390-1401.

2. Whyte RK, Canadian Paediatric Society, Fetus and Newborn Committee Safe discharge of the late preterm infant [position statement FN 2010-01]. Paediatr Child Health. 2010; 15: 665-660

3. Malley PV, Bailey S, Hendricks-Muñoz KD. Clinical issues in the management of late preterminfants. CurrProblPediatrAdolesc Health Care. 2010; 40: 218-233.

4. Canadian Institute for Health Information. Childbirth indicators by place of residence. Retrieved May 3, 2017

5. Walker M. Breastfeeding management for the late preterm infant: practical interventions for "Little Imposters". Clinical Lactation. 2010; 1: 22-26.

6. Thompson DG. Focusing on feeding skills evaluating inadequate weight gain in late preterm infants. Infant Child AdolescNutr. 2010; 2: 147-151.

7. Cleaveland K. Feeding challenges in the late preterm infant. Neonatal Netw. 2010; 29: 37-41

8. Laptook A, Jackson GL. Cold stress and hypoglycemia in the late preterm ("near-term") Infant: impact on nursery of admission. SeminPerinatol. 2006 30: $24-27$

9. Nagulesapillai T, McDonald S, Fenton T, Mercader H, Tough S. Breastfeeding difficulties and exclusivity among late preterm and term infants: results from the all our babies study. Can J Public Health. 2013; 104: 351-356.

10. Wang ML, Dorer DJ, Fleming MP, Catlin EA. Clinical outcomes of near-term infants. Pediatr. 2004; 114: 372-376.

11. Pillitteri A. Maternal and Child Health Nursing.5thedn. Los Angeles, CA Lippincott Willians\& Wilkins. 2007.
12. Garg M, Devaskar SU. Glucose metabolism in the late preterm infant ClinPerinatol. 2006; 33: 853-870.

13. Gouyon JB, lacobelli S, Ferdynus C, Bonsante F. Neonatal problems of late and moderate preterm infants. Semin Fetal Neonatal Med. 2012; 17: 146152.

14. Escobar GJ, Greene JD, Hulac P, Kincannon E, Bischoff, K, Gardner MN, et al. Rehospitalisation after birth hospitalisation: patterns among infants of al gestations. Arch Dis Child. 2005; 90: 125-131.

15. Goyal NK, Folger AT, Hall ES, Ammerman RT, Ginkel JB, Pickler RS Effects of home visiting and maternal mental health on use of the emergency department among late preterm infants. J ObstetGynecol Neonatal Nurs. 2015; 44: 135-144.

16. Jain S, Cheng J. Emergency department visits and rehospitalizations in late preterm infants. ClinPerinatol. 2006; 33: 935-945.

17. Ray KN, Lorch SA. Hospitalization of early preterm, late preterm, and term infants during the first year of life by gestational age. HospPediatr.2013; 3: 194-203.

18. Goyal NK, Attanasio LB, Kozhimannil KB. Hospital care and early breastfeeding outcomes among late preterm, early-term, and term infants. Birth. 2014; 41: 330-338.

19. Kair LR, Flaherman VJ, Newby KA, Colaizy TT. The experience of breastfeeding the late preterm infant: a qualitative study. Breastfeed Med. 2015; 10: 102-106.

20. Dosani A, Hemraj J, Premji, SS, Currie G, Reilly SM, Lodha AK, Young M, et al. Breastfeeding the late preterm infant: experiences of mothers and perceptions of public health nurses. Int Breastfeed J. 2017; 12: 23.

21. Mulcahy $\mathrm{H}$, Phelan A, Corcoran $\mathrm{P}$, Leahy-Warren $\mathrm{P}$. Examining the breastfeeding support resources of the public health nursing services in Ireland. J Clin Nurs. 2012; 21: 1097-1108.

22. Premji SS, Young M, Rogers C, Reilly S. Transitions in the early-life of late preterm infants:

23. Vulnerabilities and implications for postpartum care. J Perinat Neonatal Nurs.2012; 26: 57-68.

24. Premji SS, Currie G, Reilly S, Dosani A, Oliver LM, Lodha AK, et al. A qualitative study: mothers of late preterm infants relate their experiences of community-based care. PLoS One. 2017; 12: 0174419.

25. Fletcher AJ, Marchildon GP. Using the Delphi method for qualitative, participatory action research in health leadership. Int J Qual Methods. 2014; 13: $1-8$.

26. Dalkey N, Helmer O. An experimental application of the Delphi method to the use of experts. Manage Sci. 1963; 9: 458-467.

27. Creswell J. Qualitative Inquiry and Research Design: Choosing Among Five Approaches. Washington, DC: Sage. 2013.

28. Ziglio E. The Delphi method and its contribution to decision-making. Adler M, Ziglio E, editors. In: Gazing into the Oracle: The Delphi Method and its Application to Social Policy and Public Health. Bristol, PA: Jessica Kingsley Publishers. 1995; 3-33.

29. McDonald SW, Benzies KM, Gallant JE, McNeil DA, Dolan SM, Tough SC. A comparison between late preterm and term infants on breastfeeding and maternal mental health. Matern Child Health J. 2013; 17: 1468-1477.

30. Tedder J. Give them the HUG: An Innovative approach to helping parents understand the language of their newborn. J Perinat Educ. 2008; 17: 14-20.

31. Grummer-Strawn LM, Rollins N. Summarising the health effects of breastfeeding. ActaPaediatr. 2015; 104: 1-2.

32. Medoff-Cooper B, Bilker W, Kaplan J. Sucking behavior as a function of gestational age: a cross-sectional study. Infant Behav Dev. 2001; 24: 83-94.

33. Badr LK. Further psychometric testing and use of the maternal confidence questionnaire. Issues ComprPediatrNurs. 2005; 28: 163-174.

34. Blyth R, Creedy DK, Dennis CL, Moyle W, Pratt J, De Vries SM. Effect 
of maternal confidence on breastfeeding duration: an application of breastfeeding self-efficacy theory. Birth. 2002; 9: 278-284.

35. RadkeDemirci J, Happ MB, Bogen DL, Albrecht SA, Cohen SM. Weighing worth against uncertain work: the interplay of exhaustion, ambiguity, hope and disappointment in mothers' breastfeeding late preterm infants. Matern Child Nutr. 2015; 1: 59-72.

36. Adamkin $\mathrm{DH}$. Feeding problems in the late preterm infant. ClinPerinatol. 2006; 33: 831-837.

37. The American Academy of Breastfeeding Medicine. ABM Clinical Protoco \#10: breastfeeding the late preterm infant (340/7-366/7 weeks gestation) (First Revision June 2011). Breastfeed Med. 2011; 6: 151-156.

38. Shaker C. Reading the feeding. ASHA Lead. 2013; 18: 42-47.

39. Scher MS, Ludington-Hoe S, Kaffashi F, Johnson MW, Holditch-Davis D, Loparo KA. Neurophysiologic assessment of brain maturation after an 8-week trial of skin-to-skin contact on preterm infants. ClinNeurophysiol. 2009; 120: 1812-1818

40. Baker B, McGrath J, Lawson R, Liverman T, Cohen S. Staff nurses working together to improve care for late-preterm infants. Newborn Infant Nurs Rev. 2009; 9: 139-142.

41. Baker B. Evidence-based practice to improve outcomes for late preterm infants. J ObstetGynecol Neonatal Nurs. 2015; 44: 127-34.

42. Shaker C. Nipple feeding preterm infants: An individualized, developmentally supportive approach. Neonatal Netw. 1999; 18: 15-22.

43. Shaker C. Cue-based feeding in the NICU: using the infant's communication as a guide. Neonatal Netw. 2013; 32: 404-408.

44. Thoyre S, Shaker C, Pridham K. The early feeding skills assessment for preterm infants. Neonatal Netw. 2005; 24: 7-16.

45. Lapillonne A, O'Connor DL, Wang D, Rigo J. Nutritional recommendations for the late-preterm infant and the preterm infant after hospital discharge. J Pediatr. 2013; 162: 90-100.

46. Bakewell-Sachs S. Near-term/late preterm infants. Newborn Infant Nurs Rev. 2007; 7: 68-71.

47. Lau C. Development of suck and swallow mechanisms in infants. Ann NutrMetab. 2015; 66: 7-14.

48. Meier PP, Furman LM, Degenhardt M. Increased lactation risk for late preterm infants and mothers: evidence and management strategies to protect breastfeeding. J Midwifery Womens Health. 2007; 52: 579-587.

49. Browne JV, Ross ES. Eating as a neurodevelopmental process for high-risk newborns. ClinPerinatol. 2011; 38: 731-743

50. Hallowell S. Spatz D. The relationship of brain development and breastfeeding in the late preterm infant. J PediatrNurs. 2012; 27: 154-162.

51. Kinney HC. The near term (late preterm) human brain and risk of periventricular leucomalacia: a review. SeminPerinatol. 2006; 30: 81-88.

52. Billiards SS, Pierson CR, Haynes RL, Folkerth RD, Kinney HC. Is the late preterm infant more vulnerable to gray matter injury than the term infant? ClinPerinatol. 2006; 33: 915-933.

53. Hubbard E, Stellwagen L, Wolf $A$. The late preterm infant: $A$ little baby with big needs. ContempPediatr. 2007; 24: 51-59.

54. Lan LM, Yamashita Y, Tang Y, Sugahara T, Takahashi M, Ohba T, Okamura H. Normal fetal brain development: MR imaging with a half-fourier rapid acquisition with relaxation enhancement sequence 1. radiology. 2000; 215 : 205-210.

55. Darnall RA, Ariagno RL, Kinney HC. The late preterm infant and the control of breathing, sleep, and brainstem development: a review. ClinPerinatol. 2006; 33: 883-914.

56. Walker M. Breastfeeding management for the late preterm infant: practical interventions for "Little Imposters". Clinical Lactation. 2010; 1: 22-26.
57. Fang $P$, Kuo $H$, Huang $C$, Ko $T$, Chen $C$, Chung $M$. The effect of supplementation of docosahexaenoic acid and arachidonic acid on visual acuity and neurodevelopment in larger preterm infants. Chang Gung Med J. 2005; 28: 708-715.

58. Delaney AL, Arvedson JC. Development of swallowing and feeding: prenatal through first year of life. Dev Disabil Res Rev. 2008; 14: 105-117.

59. Miller JL, Sonies BC, Macedonia C. Emergence of oropharyngeal, laryngea and swallowing activity in the developing fetal upper aerodigestive tract: an ultrasound evaluation. Early Hum Dev. 2003; 71: 61-87.

60. Hurst N. Assessing and facilitating milk transfer during breastfeeding for the premature infant. Newborn Infant Nurs Rev. 2005; 5: 19-26.

61. Cornblath M, Ichord R. Hypoglycemia in the neonate. SeminPerinatol. 2000 14:136-149.

62. Tam EW, Haeusslein LA, Bonifacio SL, Glass HC, Rogers EE, Jeremy RJ, Barkovich AJ, Ferriero DM. Hypoglycemia is associated with increased risk for brain injury and adverse neurodevelopmental outcome in neonates at risk for encephalopathy. J Pediatr. 2012; 161: 88-93.

63. Shaker C. Cue-based co-regulated feeding in the neonatal intensive care unit: supporting parents in learning to feed their preterm infant. Newborn Infant Nurs Rev. 2013; 13: 51-55.

64. Neu J. Gastrointestinal maturation and feeding. SeminPerinatol. 2006; 30 $77-80$

65. Omari TI, Barnett C, Snel A, Goldsworthy W, Haslam R, Davidson G, et al. Mechanisms of gastroesophageal reflux in healthy premature infants. $J$ Pediatr. 1998; 133: 650-654

66. Ezaki S, Ito T, Suzuki K, Tamura M. Association between total antioxidant capacity in breast milk and postnatal age in days in premature infants. $J$ ClinBiochemNutr. 2008; 42: 133-137.

67. Newburg DS. Innate immunity and human milk. J Nutr. 2005; 135: 13081312.

68. Newburg DS. Oligosaccharides in human milk and bacterial colonization. J PediatrGastroenterolNutr. 2000; 30: 8-17.

69. Newburg DS, Walker WA. Protection of the neonate by the innate immune system of developing gut and of human milk. Pediatr Res. 2007; 61: 2-8.

70. Hurst NM, Meier PP, Engstrom JL, Myatt A. Mothers performing in-home measurement of milk intake during breastfeeding of their preterm infants: maternal reactions and feeding outcomes. J Hum Lact. 2004; 20: 178-187.

71. Watchko JF. Hyperbilirubinemia and bilirubin toxicity in the late preterm infant. ClinPerinatol. 2006; 33: 839-852.

72. Ciofani L, Johnson M. Newborn nutrition. Evans JR, Evans MK, Brown YMR editors. In: Canadian maternity, newborn, and women's health nursing: comprehensive care across the life span. $2^{\text {nd }}$ edn. Philadelphia: Wolters Kluwer. 2015; 849-886.

73. White C, Simon M, Bryan A. Using evidence to educate birthing center nursing staff: About infant states, cues, and behaviors. MCN Am J Matern Child Nurs. 2002; 27: 294-298.

74. Bu'Lock F, Woolridge MW, Baum JD. Development of co-ordination of sucking, swallowing and breathing: ultrasound study of term and preterm infants. Dev Med Child Neurol. 1990; 32: 669-678.

75. Simpson C, Schanler RJ, Lau C. Early introduction of oral feeding in preterm infants. Pediatr. 2002; 110: 517-522.

76. Adams-Chapman I. Neurodevelopmental outcome of the late preterm infant. ClinPerinatol. 2006; 33: 947-964.

77. Jorgensen AM. Late preterm infants: clinical complications and risk: part two of a two-part series. NursWomens Health. 2008; 12: 316-331.

78. Medoff Cooper B, Holditch-Davis D, Verklan MT, Fraser-Askin D, Lamp J Santa-Donato A, Onokpise B, Soeken KL, Bingham D. Newborn clinical outcomes of the AWHONN late preterm infant research-based practice project. J ObstetGynecol Neonatal Nurs. 2012; 41: 774-785. 
79. Moore ER, Anderson GC, Bergman N. Early skin-to-skin contact for mothers and their healthy newborn infants (Review). Cochrane Database of Systematic Reviews. 2009.

80. Dudell GG, Jain L. Hypoxic respiratory failure in the late preterm infant. ClinPerinatol. 2006; 33: 803-830

81. McGrath JM. "He's just a little small": helping families to understand the implications of caring for a late preterm infant. Newborn Infant Nurs Rev. 2007; 7: 120-121.

82. Meier PP, Brown LP, Hurst NM, Spatz DL, Engstrom JL, Borucki LC, Krouse AM. Nipple shields for preterm infants: effect on milk transfer and duration of breastfeeding. J Hum Lact. 2000; 16: 106-114.

83. Shapiro-Mendoza CK, Tomashek KM, Kotelchuck M, Barfield W, Weiss J, Evans S. Risk factors for neonatal morbidity and mortality among "healthy," late preterm newborns. SeminPerinatol. 2006; 30: 54-60.

84. Tomashek KM, Shapiro-Mendoza CK, Davidoff MJ, Petrini JR. Differences in mortality between late-preterm and term singleton infants in the United States, 1995-2002. J Pediatr. 2007; 151: 450-456

85. Steffensrud S. Hyperbilirubinemia in term and near-term infants: kernicterus on the rise? Newborn Infant Nurs Rev. 2004; 4: 191-200.

86. Wong DL, Perry SE, Hockenberry MJ, Lowdermilk DL, Wilson D. Maternal Child Nursing Care. $3^{\text {rd }}$ edn. St. Louis, Missouri: Elsevier. 2006.

87. Tomashek KM. Early discharge among late preterm and term newborns and risks of neonatal morbidity. SeminPerinatol. 2006; 30: 61-68.

88. Hillman N. Hyperbilirubinemia in the late preterm infant. Newborn Infant Nurs Rev. 2007; 7: 91-94.

89. Fine KL, Carey WA, Schuster JA, Bryant SC, Cook WJ, Karon BS. Defining the limitations of transcutaneous bilirubin measurement in late preterm newborns. Journal of Perinatology. 2017.

90. Bhutani VK, Johnson L. Kernicterus in late preterm infants cared for as term healthy infants. SeminPerinatol. 2006; 30: 89-97.

91. Smith JR, Donze A, Schuller L. An evidence-based review of hyperbilirubinemia in the late preterm infant, with implications for practice: management, follow-up and breastfeeding support. Neonatal Netw. 2006; 26: 395-405.

92. Bhutani VK, Johnson LH, Schwoebel A, Gennaro S. A systems approach fo neonatal hyperbilirubinemia in term and near term infants. J ObstetGynecol Neonatal Nurs. 2006; 35: 444-455.

93. Barrington KJ, Sankaran K, The Canadian Paediatric Society Fetus and Newborn Committee. Position statement: guidelines for the detection, management, and prevention of hyperbilirubinemia in term and late preterm newborn infants. Pediatr. 2007; 12: 1-12.
94. Cohen SM. Jaundice in the full term newborn. PediatrNurs. 2006; 32: 202208 .

95. Fujiwara R, Maruo $\mathrm{Y}$, Chen S, Tukey RH. Role of extrahepatic UDPglucuronosyltransferase 1A1: Advances in understanding breast milkinduced neonatal hyperbilirubinemia. Toxicology and applied pharmacology. 2015; 289: 124-32.

96. Clark L, Kennedy G, Pring T, Hird M. Improving bottle feeding in preterm infants: investigating the elevated side-lying position. Infant. 2007; 3: 154158.

97. Maastrup R, Hansen BM, Kronborg H, Bojesen SN, Hallum K, Frandsen A, Kyhnaeb A, Svarer I, Hallström I. Breastfeeding progression in preterm infants is influenced by factors in infants, mothers and clinical practice: the results of a national cohort study with high breastfeeding initiation rates. PLoS One. 2014; 9: 108208.

98. Geddes DT, Kent JC, Mitoulas LR, Hartmann PE. Tongue movement and intra-oral vacuum in breastfeeding infants. Early Hum Dev. 2008; 84: 471 477.

99. Mizuno K, Ueda A. Changes in sucking performance from nonnutritive sucking to nutritive sucking during breast-and bottle-feeding. Pediat Res. 2006; 59: 728-731.

100. Gomes CF, Trezza E, Murade E, Padovani CR. Surface electromyography of facial muscles during natural and artificial feeding of infants. J Pediatr (Rio J). 2006; 82: 103-109.

101. Yilmaz G, Caylan N, Karacan CD, Bodur I, Gokcay G. Effect of cup feeding and bottle feeding on breastfeeding in late preterm infants a randomized controlled study. J Hum Lact. 2014; 30: 174-179.

102. Lau C, Alagugurusamy R, Schanler R, Smith E, Shulman R. Characterization of the developmental stages of preterm infants during bottle-feeding. ActaPaediatr. 2000; 89: 846-852.

103. Colson SD, Meek JH, Hawdon JM. Optimal positions for the release of primitive neonatal reflexes stimulating breastfeeding. Early Hum Dev. 2008; 84: 441-449.

104. Morton J, Hall JY, Wong RJ, Thairu L, Benitz WE, Rhine WD. Combining hand techniques with electric pumping increases milk production in mothers of preterm infants. J Perinatol. 2009; 29: 757-764.

105. Ohyama M, Watabe $\mathrm{H}$, Hayasaka Y. Manual expression and electric breast pumping in the first $48 \mathrm{~h}$ after delivery. Pediatr Int. 2010; 52: 39-43.

106. Cotterman KJ. Reverse pressure softening: a simple tool to prepare areola for easier latching during engorgement. J Hum Lact. 2004; 20: 227-237.
Austin Pediatr - Volume 4 Issue 2 - 2017

ISSN : 2381-8999 | www.austinpublishing group.com

Dosani et al. (C) All rights are reserved
Citation: Dosani A and Currie G. Supporting Public Health Nurses with Breastfeeding Interventions for Late Preterm Infants. Austin Pediatr. 2017; 4(2): 1057 